\title{
Exchange Rate, Employment and Hours: What Firm-Level Data Say*
}

\author{
Francesco Nucci \\ Università di Roma "La Sapienza" \\ Alberto Franco Pozzolo \\ Università del Molise
}

January 10, 2009

\begin{abstract}
Using a representative panel of manufacturing firms, we estimate the response of job and hours worked to currency swings, showing that it depends primarily on the firm's exposure to foreign sales and its reliance on imported inputs. Further, we show that, for given international orientation, the response to exchange rate fluctuations is magnified when firms exhibit a lower monopoly power and when they face foreign pressure in the domestic market through import penetration. The degree of substitutability between imported and other inputs and the distribution of workers by type introduce additional degrees of specificity in the employment sensitivity to exchange rate swings. Further, wage adjustments are also shown to provide a channel through which firms react to currency shocks. Finally, gross job flows within the firm are found to depend on exchange rate fluctuations, although the effect on job creation is predominant.
\end{abstract}

JEL classifications: E24; F16; F31.

Keywords: Employment; Exchange Rate; Firm's Foreign Exposure.

\footnotetext{
${ }^{*}$ This project was begun while Alberto Pozzolo was with the Research Department of the Bank of Italy. We thank Luca De Benedictis, Linda Goldberg, Jean Imbs, Roberto Tedeschi and seminar participants at EIEF, the IEA Conference (Istambul), the University of Molise and the Meeting of the CNR Group on International Economics for useful comments. Pietro Cova helped us with Banca d'Italia's effective exchange rates. E-mail addresses: francesco.nucci@uniroma1.it; pozzolo@unimol.it.
} 


\section{Introduction}

Do exchange rate fluctuations affect employment and hour decisions across firms? While there is a substantial literature assessing the implications for the real economy of exchange rate swings, with some contributions indeed focusing on the effects on labor market variables, there is little evidence at the microeconomic level on the employment and hours response to currency movements. In this paper, we investigate this relationship in detail, analyzing the transmission channels at the firm level of an exchange rate shock to jobs and hours worked.

There are at least two major reasons why focusing on firm level data is particularly appropriate for studying the relationship between employment and exchange rates. First, this level of disaggregation permits a better understanding of the mechanisms a the hearth of the relationship between the exchange rate and the level of employment that has indeed been found on more aggregate data. Second, it permits to appraise how exchange rate fluctuations can have very heterogenous effects on firms with different characteristics.

The existing literature in this area can be broadly divided in two distinct groups. A first set of contributions deals with the influence of exchange rate and, in general, international factors on net employment, either at aggregate or at industry level (Branson and Love, 1988; Revenga, 1992; Burgess and Knetter, 1998; Goldberg and Tracy, 2000; Campa and Goldberg, 2001). A more recent body of theoretical and empirical research, based on the flow approach to labor markets, investigates instead the impact of the exchange rate on gross job flows and, more in general, on the process of inter- and intra-industry employment reallocation (Gourinchas, 1998 and 1999; Klein et al., 2002 and 2003).

In our study, we single out and investigate a variety of channels through which the currency value affects the firm's labor demand and net employment. Following Campa and Golberg (2001), we characterize the direction and magnitude of labor response as primarily depending on the producers' external orientation through both exports and imported inputs use. However, differently from their

study, we do find a statistically significant and non negligible effect of exchange rate movements on both employment and hours worked. The existence of such effect is separately uncovered on the revenue side, through exposure to foreign sales, and on the cost side, through reliance on imported inputs.

It is our belief that Campa and Goldberg's finding of a low degree of responsiveness of labor input 
to exchange rate fluctuations, and thus the divergence with our own results, depends on their use of data aggregated at the industry level. Indeed, an extensive volume of gross job flows has been widely documented also within narrowly defined industries. As a result, the effect of exchange rate appraised on aggregate net employment would easily hide the effects on intra-sector job reallocation (Gourinchas, 1999). More generally, recent work on labor decisions underlines the importance of firms' heterogeneity and individual specific aspects, which are difficult to track in the aggregate data (see, e.g., Davis and Haltiwanger, 1999). For these reasons we analyze the responsiveness of employment and hours worked to exchange rate fluctuations using firm-level panel data from two high-quality sources: the Bank of Italy Survey of Investment in Manufacturing and the Company Accounts Data Service reports. The period we analyze is antecedent the introduction of the single European currency and provides a very interesting case study, as Italy experienced significant exchange rate oscillations for a developed country, and was at the same time characterized by a high degree of firms' external orientation on both the revenue and cost sides.

To highlight the different channels through which exchange rate variations affect firms' decisions on labor input, we first present a simple theoretical model, providing a set of testable implications that naturally lend themselves to the empirical scrutiny. The model shows that after an exchange rate swing - for concreteness a depreciation - the more a firm relies on imported inputs, the larger is the increase in its costs, the reduction in marginal profitability, and the ensuing drop in employment and hours worked. At the same time, in the aftermath of a depreciation the higher is the firm's external sale exposure - i.e., the share of revenues from exports in total revenues - the larger is the increase in its sales, in marginal profitability and therefore in the use of labor input.

An additional important implication of the theoretical model is that the sensitivity of employment and hours worked to exchange rate fluctuations depends on the firm's degree of monopoly power. There are two channels through which market power affects the relationship. The first is related to the price elasticity of demand. For a given (nonzero) exchange-rate pass-through to destination market prices, a depreciation causes a reduction of the export price in foreign currency, inducing a rise in volumes sold in the foreign market (and, thereby, in profitability and labor demand), which is positively related to the price elasticity of foreign demand faced by the firm. Since such elasticity is inversely related to the firm's degree of market power, the latter introduces an additional source of heterogeneity in the labor response to the exchange rate. In other words, for a given firm's external orientation, the effect of exchange rate swings on employment is magnified if firms exhibit low market power. The second channel is related to the extent to which firms "pass-through" an exchange rate shock into export prices expressed in foreign currency. In particular, everything else held constant, the lower is the exchange rate pass-through into destination market prices - i.e., the 
more stable are local-currency prices - the higher is the labor inputs sensitivity to currency shocks. Indeed, as shown in a number of contributions analyzing the relationship between exchange rates and prices (see, e.g., Dornbusch, 1987; Knetter, 1993; Yang, 1997), the market structure affects the degree of exchange rate pass-through into export prices denominated in foreign currency. In particular, the pass-through is shown to be more pronounced if product differentiation is high, if the degree of substitution among different variants of goods is low and, in general, if the exporter faces a low degree of competition in the foreign market, having thus a higher pricing power.

Our empirical findings are consistent with the model's predictions that the sensitivity of employment and hours worked to exchange rate fluctuations is higher for firms with low market power. Moreover, in the empirical analysis we single out three additional firm-specific features that are potentially relevant for characterizing the exchange rate-labor input link at the firm level. First, we consider the degree of import penetration in the domestic market where the firm operates. In industries where the share of imports over total demand is high, firms with a larger dependence on domestic revenues are more exposed to foreign competition and therefore to the effects of exchange rate swings. In other words, if import penetration is high in a given industry, then a currency appreciation would severely reduce competitiveness of domestic firms, the more so for firms with a high internal orientation of their sales. Second, we consider the degree of substitutability in the production function between imported and domestically produced inputs. If technological features or market constraints prevent imported inputs from being substituted with other inputs, then an exchange rate swing is likely to yield a more pronounced impact on employment and hours worked, as firms profitability would be more deeply affected by the external shock. Finally, we study whether the job and hours response to currency movements may depend on the distribution of workers by type of job within each firm (i.e., blue- vs. white-collars). This would would clearly be the case if the firm's ability to adjust its labor force hinged on the type of workers that it employs.

Our analysis focuses also on the wage response to exchange rate movements. The theoretical model provides some testable implications on this regard. Whilst our results for the response of employment and hours worked are quite different from those of Campa and Goldberg (2001), when we turn to investigate the wage response the findings are more similar, with a statistically significant influence of exchange rate movements on wages. As we discuss in more detail below, the fact that a significant wage response is uncovered also at the industry level does not play down the importance of job reallocation within industries. Indeed, following a currency movement, some jobs can be lost and some can be created within the same industry. However, if the wage packages offered to those taking the new jobs were different from those characterizing the disappeared jobs, then there would 
be significant wage changes at the industry level even without controlling for labor reallocation. ${ }^{1}$

A further characterization of the transmission of exchange rate shocks to firm-level employment deals with gross job flows. Differently from the literature mentioned above on the impact of exchange rate on inter- and intra-industry job reallocation (Gourinchas, 1998 and 1999; Klein et al., 2002 and 2003), in our analysis we simply verify whether the net employment change following an exchange rate swing is accompanied by a considerable degree of job reallocation within the firm. Our results show that exchange rate swings significantly affect the rate of job reallocation within each firm. We also provide evidence, however, that this effect is driven primarily by the exchange rate impact on job creation rather than on job destruction.

The remainder of the paper is organized as follows. Section 2 presents the theoretical framework and outlines the transmission channels of exchange rate shocks to employment and hours worked. Section 3 describes the data used and illustrates the empirical specification. Section 4 documents the empirical results from the baseline specification and Section 5 provides some further characterizations of the link between exchange rate and labor variables, dealing with the wage response and with the implications for job reallocation within each firm. Section 6 concludes.

\section{Theoretical Framework}

In this section we present a simple model of the labor market that allows us to illustrate the mechanisms through which exchange rate variations affect the level of employment. The labor demand schedule is derived from the first order conditions for profit maximization of a firm operating in an imperfectly competitive market. Following Campa and Goldberg (2001), the labor supply schedule is assumed to be a simple increasing function of the real wage and of aggregate demand conditions. In this framework, exchange rate variations affect labor demand through changes in the firm's marginal revenue product of labor. An exchange rate depreciation affects firm's profits through two major channels: an increase in the price of imported inputs and a decrease in the price in foreign currency of exported products. ${ }^{2}$ The effect on the expenditure side clearly depends on a number of firm specific characteristics, most notably its reliance upon imported inputs and the elasticity of substitution between such inputs and domestically produced substitutes. The effect on the foreign sale side depends primarily on the share of revenues from exports in total revenues, on

\footnotetext{
${ }^{1}$ Along these lines, Campa and Goldberg (2001) argue convincingly that the problems of aggregation are less problematic in estimating real wage elasticities than they are in estimating employment elasticities.

${ }^{2}$ For expositional clarity, in the following we will focus, in general, on the case of exchange rate depreciation; the case of appreciation is symmetric.
} 
the firm's market power in the product market, and on the degree of exchange rate pass-through into export prices in local currency.

\section{$2.1 \quad$ The model}

Consider, for simplicity, the static problem of a firm that has the objective of maximizing its profits, $\pi$, taking as given: a) the available technology, described by a constant return to scale production function, $Q=F\left(L, z, z^{*}\right)$, where $L$ is labor input and $z$ and $z^{*}$ are the levels of domestically produced and imported non-labor inputs, respectively; b) the prices of the domestically produced and the imported inputs, respectively $s$ and $s^{*}$, expressed in local currency; c) the level of the exchange rate, $e$, expressed as the number of foreign currency units per domestic currency unit, so that a decrease in the exchange rate amounts to a depreciation.

The firm's choice variables are: a) the amount of product to supply in the domestic market and in the foreign markets, respectively $q$ and $q^{*}$; b) the volume of domestic and foreign non-labor inputs, respectively $z$ and $z^{*}$; c) the amount of labor to be hired, $L$.

Substituting the inverse demand functions into the profit function, the firm's problem can be defined as:

$$
\pi(e)=\max _{q, q^{*}, z, z^{*}, L} p(q, e) q+\frac{p^{*}\left(q^{*}, e\right) q^{*}}{e}-z s-\frac{z^{*} s^{*}(e)}{e}-w L,
$$

subject to the technology constraint:

$$
q+q^{*}=Q=F\left(L, z, z^{*}\right)
$$

The first order conditions with respect to $q$ and $q^{*}$ for the solution of the constrained maximization problem (??) are:

$$
\begin{aligned}
\frac{\partial p(q, e)}{\partial q} q+p-\lambda & =0 \\
\frac{\partial p^{*}\left(q^{*}, e\right)}{\partial q^{*}} \frac{q^{*}}{e}+\frac{p^{*}}{e}-\lambda & =0 .
\end{aligned}
$$

where $\lambda$ is the Lagrange multiplier for the technology constraint. By defining the price elasticities of demand in the domestic and in the foreign product market respectively as $\eta=\frac{\partial q}{\partial p} \frac{p}{q}$ and $\eta^{*}=\frac{\partial q^{*}}{\partial p^{*}} \frac{p^{*}}{q^{*}}$, it is possible to obtain, from equations (??) and (??) the following relationship, linking prices and demand elasticities in the home and foreign markets:

$$
\lambda=p\left(1+\frac{1}{\eta}\right)=\frac{p^{*}}{e}\left(1+\frac{1}{\eta^{*}}\right) .
$$


Similarly, the optimal conditions with respect to $z, z^{*}$ and $L$ are:

$$
\begin{aligned}
-s+\lambda \frac{\partial F\left(L, z, z^{*}\right)}{\partial z} & =0, \\
-\frac{s^{*}(e)}{e}+\lambda \frac{\partial F\left(L, z, z^{*}\right)}{\partial z^{*}} & =0, \\
-w+\lambda \frac{\partial F\left(L, z, z^{*}\right)}{\partial L} & =0 .
\end{aligned}
$$

Combining (??) with the above three equations, we can obtain the following equilibrium conditions, equating the marginal revenue product of each input to its marginal cost:

$$
\begin{aligned}
\frac{\partial F\left(L, z, z^{*}\right)}{\partial z} & =\frac{s}{p\left(1+\frac{1}{\eta}\right)}, \\
\frac{\partial F\left(L, z, z^{*}\right)}{\partial z^{*}} & =\frac{s^{*}(e)}{p^{*}\left(1+\frac{1}{\eta^{*}}\right)}, \\
\frac{\partial F\left(L, z, z^{*}\right)}{\partial L} & =\frac{w}{p\left(1+\frac{1}{\eta}\right)} .
\end{aligned}
$$

With a constant returns to scale production function, by applying Euler's theorem we can express total output as the sum of the products of marginal productivity of each factor and the quantity of input used:

$$
Q=F\left(L, z, z^{*}\right)=\frac{\partial F\left(L, z, z^{*}\right)}{\partial L} L+\frac{\partial F\left(L, z, z^{*}\right)}{\partial z} z+\frac{\partial F\left(L, z, z^{*}\right)}{\partial z^{*}} z^{*}
$$

Defining $\frac{1}{\mu}=\left(1+\frac{1}{\eta}\right)$ and $\frac{1}{\mu^{*}}=\left(1+\frac{1}{\eta^{*}}\right)$ as the reciprocals of the mark-ups set, respectively, in the domestic and foreign product markets, and substituting equations (??)-(??) into (??), simple algebraic manipulations yield the following equilibrium condition, which links the firm's total costs and its revenues in the home and foreign markets, adjusted for the destination market mark-up:

$$
w L=\frac{p q}{\mu}+\frac{e p^{*} q^{*}}{\mu^{*}}-\left(s z+\frac{s^{*} z^{*}}{e}\right)
$$

In order to fully characterize the labor market, we need to introduce a labor supply schedule. Following Campa and Goldberg (2001), we assume that labor supply is a linear function of the wage, $w$, and of aggregate demand conditions, $y$ :

$$
L=a_{0}+a_{1} w-a_{2} y
$$

where $a_{1}$ and $a_{2}$ are assumed to be a positive constants and their size reflects preferences and other labor supply features. 
Solving equation (??) with respect to the wage, $w$, and substituting it into equation (??), yields an equilibrium relationship for the labor market that depends on the variables assumed to be exogenous in our model: the exchange rate, $e$, the prices of non-labor domestic and imported inputs, $s$ and $s^{*}$, and the level of aggregate demand, $y$. In equilibrium:

$$
L\left(\frac{L-a_{0}+a_{2} y}{a_{1}}\right)=\mu^{-1} p q+\mu^{*-1} \frac{p^{*} q^{*}}{e}-s z-\frac{s^{*} z^{*}}{e} .
$$

By totally differentiating equation (??) with respect to $L$ and $e$, it is possible to evaluate the effect of exchange rates variations on the equilibrium level of employment. In particular, taking into account that prices in the domestic and in the foreign product markets are functions of the quantity produced and of the exchange rate, and assuming the price elasticities of demand to be constant, we obtain the following expression:

$$
\frac{2 L-a_{0}+a_{2} y}{a_{1}} \Delta L=\frac{\partial p}{\partial e} q \mu^{-1} \Delta e+\frac{\partial p^{*}}{\partial e} \frac{q^{*} \mu^{*-1}}{e} \Delta e-\frac{p^{*} q^{*} \mu^{*-1}}{e^{2}} \Delta e+\frac{s^{*} z^{*}}{e^{2}} \Delta e-\frac{\partial s^{*}}{\partial e} \frac{z^{*}}{e} \Delta e .
$$

Equation (??) can be simplified and given more information content by using the definitions of mark-up provided above and rearranging the terms as functions of: a) the share of sales on foreign markets in total sales, $\chi \in[0,1]$; b) the share of production costs on imported inputs in total costs, $\alpha \in[0,1]$; c) the elasticities of domestic and foreign prices with respect to the exchange rate, respectively, $\eta_{p, e} \in[-1,0]$ and $\eta_{p^{*}, e} \in[0,1]$, (i.e., the pass-through elasticities); d) the elasticity of foreign input prices with respect to the exchange rate, $\eta_{s^{*}, e} \in[0,1]$; e) the value of total revenues expressed in domestic currency, $T R$. Indeed, after some algebraic manipulations - and using the fact that, under constant returns to scale, total revenues can be considered as approximately equal to total costs times the (average) mark-up ${ }^{3}$ - the elasticity of equilibrium employment with respect to the exchange rate can be expressed as follows:

$$
\frac{\Delta L}{\Delta e} \frac{e}{L}=\frac{T R}{\bar{\mu}}\left[(1-\chi) \eta_{p, e}-\chi\left(1-\eta_{p^{*}, e}\right)+\alpha\left(1-\eta_{s^{*}, e}\right)\right] \frac{a_{1}}{L\left(2 L-a_{0}+a_{2} y\right)}
$$

where $\bar{\mu}$ is the average value of the mark-up in the home and foreign markets (respectively, $\mu$ and $\left.\mu^{*}\right)$.

Substituting directly equation (??) into (??) and following a procedure similar to that described above, we can also obtain an expression for the elasticity of wages with respect to the exchange rate:

$$
\frac{\Delta w}{\Delta e} \frac{e}{w}=\frac{T R}{\bar{\mu}}\left[(1-\chi) \eta_{p, e}-\chi\left(1-\eta_{p^{*}, e}\right)+\alpha\left(1-\eta_{s^{*}, e}\right)\right] \frac{1}{w\left(a_{0}+2 a_{1} w-a_{2} y\right)}
$$

\footnotetext{
${ }^{3}$ Under constant returns to scale, the mark-up, given by the ratio of prices to marginal costs, is approximately equal to the ratio of prices to average costs. We therefore obtain that total revenues can be expressed as the product of the mark-up and total costs.
} 
Equations (??) and (??) represent a useful theoretical background for our empirical analysis, providing a variety of testable implications that lend themselves to the data scrutiny. The following section discusses in more detail the number of channels, explicitly identified in our theoretical model, through which exchange rate movements affect employment, hours worked and wages.

\subsection{The propagation mechanism}

A first implication of equations (??) and (??) is that the firm's external orientation towards international markets is pivotal in shaping the direction and size of the effect on employment, hours worked and wages of exchange rate variations. The transmission of exchange rate variations is through its effects on the marginal revenue product of labor and, therefore, on profits. It is important to emphasize that the expression $(1-\chi) \eta_{p, e}-\chi\left(1-\eta_{p^{*}, e}\right)$ in the previous equations is clearly non-positive, given that $\chi \in[0,1], \eta_{p, e} \in[-1,0]$ and $\eta_{p^{*}, e} \in[0,1]$. Therefore, an exchange rate depreciation (i.e., a decrease in $e$ ) has a positive effect on employment (and wages) through the revenue channel. ${ }^{4}$ Moreover, the higher is the share of foreign sales in total sales, $\chi$, the stronger is the increase in employment induced by an exchange rate depreciation. ${ }^{5}$ On the contrary, the expression $\alpha\left(1-\eta_{s^{*}, e}\right)$ is nonnegative, since $\eta_{s^{*}, e} \in[0,1]$, indicating that the same depreciation has a negative effect on employment through the cost channel. By the same token, the higher is firms' reliance on imported inputs relatively to total input purchases, $\alpha$, the more sizeable is the employment decrease following an exchange rate depreciation.

In addition to these basic elements that characterize firm's orientation to foreign markets, the theoretical model highlights two important additional features that affect the sign and size of the exchange rate elasticity of employment and hours worked. The first deals with the higher sensitivity of employment to exchange rate in firms exhibiting a lower market power, captured in equation (??) by the negative relationship of the employment elasticity with respect to the mark-up index, $\bar{\mu}$. The intuition for this result is the following. For a given extent of foreign exposure, $\chi$, and for a given (nonzero) value of the exchange-rate pass-through elasticity, $\eta_{p^{*}, e}$, the reduction in the foreign-currency export price induced by an exchange rate depreciation generates an increase of the quantity of products sold in the foreign market, $q^{*}$, - and, as a consequence, of profitability and labor input - which is larger the higher is the price elasticity of foreign demand. As it is well known, such elasticity is negatively related to the firm's degree of market power, so that the sensitivity to

\footnotetext{
${ }^{4}$ For simplicity, in the following we will focus mainly on the effects on employment; the effects on hours worked are equivalent.

${ }^{5}$ A necessary and sufficient condition for the "magnification" effect of foreign exposure to hold is that the sum of the (absolute values of) exchange-rate pass-through elasticities be smaller than one (i.e., $\left|\eta_{p, e}\right|+\eta_{p^{*}, e}<1$ ).
} 
exchange rate of employment is amplified when firm's market power is low.

The second additional insight of the model is that also the degree of exchange-rate pass-through may influence the employment sensitivity to currency swings. The pass-through elasticity in the foreign market, $\eta_{p^{*}, e}$ - ranging from zero (no pass-through) to one (complete pass-through) - measures how much the firm is willing to change the prices set in the foreign market as a result of exchange rate variations. It is clear from equation (??) that the lower is the pass-through of exchange rate into foreign-currency export prices, $\eta_{p^{*}, e}$, the stronger is the employment and hour response to exchange rate fluctuations. The relationship between exchange rates and prices have been widely analyzed and many studies have focused primarily on how the degree of exchange-rate pass-through to export prices is determined by the market structure. A notable finding in the theoretical and empirical literature is that the degree of pass-through is less pronounced - i.e., foreign-currency prices tend to be more stable - when products are scarcely differentiated and the extent of their substitution among different variants is high (Yang, 1997). In general, the pass-through tends to be low if the exporting firm faces a high degree of competition in the foreign market and consequently has a limited pricing power (see, e.g., Dornbusch, 1987; Knetter, 1993). Clearly, if the foreign market is perfectly competitive, so that the firm is a price taker, the pass-through elasticity is null and an exchange rate appreciation has a one-to-one effect on the value of foreign sales expressed in the domestic currency.

Next, consider the channel going through domestic sales. By making foreign products less expensive, a currency appreciation decreases the competitiveness of domestic firms, causing a reduction of its sales in the home market, and therefore a drop in its profitability and employment. Again, market structure plays a crucial role on this respect and the mechanism is similar to the one described above. The domestic pass-through elasticity ranges from minus one (complete pass-through) to zero (no pass-through), and (in absolute value) it is a decreasing function of the firm's market power in the domestic market. In the limiting case of perfect competition in the domestic market because of strong competitive pressure from foreign producers, the reduction in the price of imported goods determined by a currency appreciation must be rebated by a one-to-one price reduction by the domestic firm (i.e., the pass-through elasticity is minus one). Hence, a currency appreciation causes a reduction in the value of domestic sales, that is stronger the lower is the firm's monopoly power. Moreover, as explained convincingly by Dornsbusch (1987) and Campa and Goldberg (2001), the domestic pass-through elasticity is proportional to the degree of import penetration, that summarizes the amount of pressure in the domestic market exerted by foreign producers. We will consider such dependence in our empirical analysis.

Similar to the sale side, the effect of an exchange rate depreciation on employment coming from 
the increase in the cost of imported inputs also depends on the degree of competition in the market for inputs. The closer to zero is the elasticity of foreign input prices to the exchange rate, $\eta_{s^{*}, e}-$ which ranges from zero (no pass-through) to one (complete pass-through) - the larger is the effect of exchange rate variations on employment.

\section{$3 \quad$ Data and summary statistics}

Our empirical analysis is conducted using firm level data obtained from the Survey of Investment in Italian Manufacturing and from the Company Accounts Data Service reports. The Survey of Investment has been carried out every year since 1984 by the Bank of Italy on a stratified sample of over 1,000 firms with more than 50 employees. It collects information at the firm level on a wide set of economic variables, including total employment, hours worked, total revenues and revenues from foreign sales. The Company Accounts Data Service reports contain detailed balance-sheet information on a sample of around 40,000 firms. Merging the information from the two sources resulted in an unbalanced panel of slightly less than 2,400 firms. ${ }^{6}$

Because neither of our data sources provide distinct information on domestically produced and imported non-labor inputs, as in Nucci and Pozzolo (2001) we supplement the available firm-level information on purchases of materials and services and on labor costs with data from the 44-sectors input-output table of 1992 for the Italian economy. In particular, for each industry we select the values of intermediate inputs imported and also of all inputs purchased, both domestically produced and imported. We then use economic time series on import demand and production for each industry to update (backward and forward) the corresponding figures of the input-output table. Finally, in computing $\alpha_{i t}$, the share of expenditure on imported inputs in total input purchases of firm $i$ at time $t$, we combine the industry-level information with data on firm's expenditure for materials and services and for labor inputs. ${ }^{7}$

Each firm's market power is computed as the ratio of profit margins to unit price. Due to lack of

\footnotetext{
${ }^{6}$ In order to verify that the survival rate of firms in the sample is not affected by exchange rate movements, we estimated a logit model on our data, where the firm-level dependent variable takes the value of one if the firm exited from the sample the previous year and zero if the firm is in the sample in a given year. The explanatory variables are the one-period lagged exchange rate variation and a set of control dummy variables. The regression results indicate that the estimated coefficient of the exchange rate is not statistically different from zero.

${ }^{7}$ In particular, the firm-level share of expenditure on imported inputs in total expenditure is defined as $\alpha_{i t}=$ $\frac{\left(\frac{I M_{j t}}{T E_{j t}}\right) T E_{i t}}{T E_{i t}+L C_{i t}}$ to), $T E_{i t}$ and $T E_{j t}$ are the values of non-labor expenditure for intermediate inputs of, respectively, firm $i$ and industry $j$, and $L C_{i t}$ is labor costs of firm $i$.
} 
information on foreign profits, we cannot distinguish between the mark-ups in the home and foreign markets. As suggested by Domowitz et al. (1986), we adopt the following time-varying measure: ${ }^{8}$

$$
\text { mkup }_{i t}=\left(\frac{\text { sales }+ \text { change in inventories }- \text { payroll }- \text { cost of non-labor inputs }}{\text { sales }+ \text { change in inventories }}\right)_{i t}
$$

We measure currency oscillations using the export and the import real effective exchange rates of the lira computed by the Bank of Italy, each one taking into account 24 bilateral exchange rates. For the export rate, the weights reflect: a) the shares of Italian export towards each of the 24 countries; b) the weight of each country's exports in satisfying the domestic demand of all 24 trade partners; c) the domestic demand that originates from each country. For the import rate, the weights simply reflect the geographic composition of Italian imports. The two real exchange rates are computed using producer price indexes (Banca d'Italia, 1998). In presence of even small adjustment costs, firms are unlikely to modify their employment level after temporary fluctuations in the exchange rates. For this reason, we derived the permanent component of exchange rate variations using the Beveridge and Nelson (1981) procedure that decomposes an I(1) time series into its permanent and transitory components. Since the real exchange rate we use are trade-weighted multilateral indices, following Campa and Golberg (2001) we relied on a univariate decomposition procedure. In particular, we selected an autoregressive model for both the export and import monthly (log) real exchange rate change. From our decomposition, the transitory component accounts for only a small fraction of the variance of the actual change in the exchange rate. Consistent with the specification in the theoretical model, a reduction in the exchange rate is a (real) depreciation.

Table 1 documents the summary statistics for the most important variables used in our empirical analysis. The mean rate of change of the import exchange rate is 0.00 during the sample period, but the standard deviation is 0.05 and the values at the first and third quartiles are -0.03 and 0.02 , respectively, suggesting that there is a non negligible variability in the sample studied. In the case of the export exchange rate, the mean rate of change is -0.01 , but the standard deviation suggests an even larger variability. The average degree of firm's dependence on imported inputs is 14 per cent, with a distribution slightly skewed to the right, as suggested by the lower median level. The average share of revenues from export in total revenues, 31 per cent, is more than twice that of import dependence, and also in this case there is evidence of right skewness. Interestingly, even at the 25th percentile the share of revenues from export is economically quite significant, at 5 per cent. The mean and median mark-ups are 9 per cent, with a substantial dispersion. The average and median rates of growth of employment, hours worked, wages and total sales are all rather

\footnotetext{
${ }^{8}$ The empirical measure of mark-up defined above has a strict relationship with the index discussed in the theoretical section: $m k u p=\frac{(\bar{\mu}-1)}{\bar{\mu}}$, assuming no changes in inventories.
} 
low, about one per cent in absolute terms. However, also in this case there is a high variability across firms and time, as shown by the high standard deviation and the negative values of the 25th percentile level compared to the positive values of the 75 th percentile.

\subsection{The Empirical Specification and Estimation}

Based on the testable insights from the theoretical framework developed in Section 2 (i.e., equation (??)), we specify the following dynamic equations for labor input:

$$
\Delta n_{i t}=\beta_{0}+\beta_{1} \alpha_{i t-1} \Delta e_{t}+\beta_{2} \chi_{i t-1} \Delta e_{t}+\beta_{3} \Delta s_{i t-1}+\beta_{4} m k u p_{i t-1}+\beta_{5} \Delta n_{i t-1}+b^{\prime} Z_{i t}+\lambda_{i}+u_{i t}
$$

where lower-case letters refer to the logarithmic transformation of the variable, $n_{i t}$ is the level of labor input of firm $i$ at time $t, s_{i t}$ denotes the value of real sales and $e_{t}$ is the real effective exchange rate, expressed as before in terms of number of foreign currency units per unit of domestic currency, so that an increase in the exchange rate amounts to an appreciation. $Z_{i t}$ is a vector of dummy variables referring to the year, the industry, the size and the geographic location of each firm. As labor input measures, we alternatively use the number of employees and the amount of hours worked.

To appraise the implications for firm's labor variables of exchange rate swings, the key elements are the two interaction terms of the exchange rate change with, respectively, $\alpha_{i t-1}$, the share of costs for imported inputs in total variable costs, and $\chi_{i t-1}$, the share of export sales in total sales, both lagged of one year to mitigate the possible simultaneity bias arising from the effect of exchange rate on the degree of firm's external orientation. As illustrated in the previous sections, these two variables reflect the firms' exposure to international competition in foreign input markets (cost side) and foreign product markets (revenue side), respectively. By interacting the exchange rate changes, $\Delta e_{t}$, with the firm-specific, time-varying external orientation variables $\left(\alpha_{i t-1}\right.$ and $\left.\chi_{i t-1}\right)$, our empirical specification allows the estimated effect of exchange rate on labor input to vary over time and across firms, depending on the two variables shaping the extent of firm's foreign exposure.

As discussed above, and following Campa and Goldberg (2001), we single out more precisely the relevant effects of the currency value in the interaction terms, $\alpha_{i t-1} \Delta e_{t}$ and $\chi_{i t-1} \Delta e_{t}$, using the permanent component of the (log) change of, respectively, the import and export exchange rates, $e_{t}$. The reason for using the permanent components is that the theoretical model developed in section 2 can be seen as nested in a more general multi-period, stochastic firm's optimization problem. Indeed, under the two hypotheses that the unique source of uncertainty in the model is the exchange rate and that the latter follows a random walk, it has been shown that all model 
predictions from a multi-period set-up, which are relevant for our research purposes, can be suitably obtained and investigated in a simpler framework such as the one devised in this paper (Campa and Goldberg, 1999 and 2001; Nucci and Pozzolo, 2001). Indeed, if the exchange rate follows a random walk, then the conditional expected value of future exchange rate is equal to today's realization and the effects of any exchange rate variation are persistent. Therefore, for establishing a closer link between an implicit assumption of the model and the empirical analysis, it is appropriate to focus on the permanent component of exchange rate fluctuations. On the other hand, as mentioned above, the outcome of the Beveridge and Nelson decomposition suggests that the transitory component of changes in the currency value accounts for only a small fraction of the variance of actual exchange rate variations. Indeed, our empirical results are substantially unchanged if the actual values of exchange rate variations, instead of their permanent component, are used.

In addition to year dummies, controlling for time-varying effects common to all firms, the empirical specification allows for a firm-specific latent heterogeneity by including fixed effects, $\lambda_{i}$. The error terms of the specification above, $u_{i t}$, are assumed to have finite moments with $E\left(u_{i t}\right)=E\left(u_{i t} u_{i s}\right)=$ 0 , for all $t \neq s$. A lagged value of the dependent variable is included in the equation to control for serial correlation: the latter may originate, for example, from the adjustment lags typical of employment changes. We also insert the change in the value of firm's real sales to account for demand conditions and the lagged value of the mark-up, to account for the effect of marginal profitability that is independent of the exchange rate shock.

In estimating the baseline equation (??), as well as a number of extensions, we use the generalized method of moments (GMM) estimator developed for dynamic panel data model (Arellano and Bond, 1991; Arellano and Bover, 1995; Blundell and Bond, 2000). The reason we rely on such methodology is that, in the specification above, the lagged values of the dependent variable, of real sales and the mark-up are correlated with the individual fixed effects, $\lambda_{i}$. This would yield a specification error inducing inconsistency of the parameter estimates. The GMM estimator for panel data controls for the endogeneity of the regressors and restores consistency of parameters' estimates. Moreover, this estimator turns out to be efficient within the class of instrumental variable estimators. Following Arellano and Bover (1995) and Blundell and Bond (2000), we use the system GMM panel estimator. The latter augments the Arellano and Bond (1991) estimator by building a system of two equations: the original equation and a transformed one. As in Arellano and Bond (1991), in the transformed equation a variety of instruments in levels can be used. However, under the novel approach a further assumption is made: that first differencing the instrumenting variables in the original equation make them uncorrelated with fixed effects. This allows one to exploit an even larger number of orthogonality conditions than before, by resorting to a larger instrument set. 
Consistently with this approach, as GMM-type of instruments we selected the lagged values of the dependent variable, of real sales and of the mark-up dated period $t-2$ and earlier. We also test for instruments exogeneity and, in general, for validity of the specification. We do so by performing the Hansen test of over-identifying restrictions, that allows to verify the orthogonality between

instruments and errors. Such test statistic is distributed as $\chi^{2}$ with degrees of freedom equal to the number of over-identifying restrictions. We also perform the Arellano-Bond test for second-order serial correlation based on residuals from the transformed equation; the asymptotic distribution of this test statistic is standard normal (Arellano and Bond, 1991).

In the following section, we document and discuss the results from applying the GMM estimation method to our empirical specification for microeconomic data.

\section{The Baseline Results}

The baseline empirical specification illustrated in the previous section provides a suitable framework for examining the testable implications of our theoretical model. In the following, we will present the results of the basic specification and of the extensions analyzing the effects of the firm's market power on the transmission mechanisms.

\subsection{International Exposure, Employment and Hours}

The econometric results lend support to the view that exchange rate fluctuations have a significant effect on employment and hours worked. In table 2 (column 1 and 2) we report the findings from estimating equation (??) using the number of employees of each firm as dependent variable. The difference among the two specifications is that in column 1 the mark-up term is excluded. The coefficient measuring the effect of exchange rate variations through changes in the proceeds from foreign sales is always negative and significantly different from zero at the 95 per cent level (in column 2 it is -1.169 with a standard error of 0.186 ); the estimated coefficient measuring the effect through the change in costs for imported inputs is always positive and also statistically significant at the 95 per cent level (in column 2 it is 2.432 with a standard error of 0.958 ). Therefore, an exchange rate depreciation, as measured by a reduction of import and export exchange rates (respectively, pmer $_{t}$ and peer $_{t}$ ) induces an employment expansion through the revenue side of the balance sheet and a contraction through the cost side. Moreover, the effect stemming from the revenue side increases, in absolute value, with the firm's share of foreign sales in total revenues $\left(\chi_{i t}\right)$, while the effect on the cost side is increasing in the share of expenditure for foreign inputs in total costs 
$\left(\alpha_{i t}\right){ }^{9}$

The fact that the coefficients associated to $\alpha_{i t-1} \cdot \Delta p m e r_{t}$ and $\chi_{i t-1} \cdot \Delta p e e r_{t}$ have both the expected signs and exhibit large statistical significance is somewhat at odds with the results documented by Campa and Goldberg (2001) for the U.S. economy. In their contribution, when focusing on the whole sample of manufacturing industries, they find that the estimated parameters of those two variables are not statistically significant, leading them to the conclusion that the effects of exchange rate swings on jobs and hours worked are relatively small. We believe that this divergence in findings is not attributable to structural differences between the Italian and the U.S. economy. On this regard, if anything, we would expect that a country like Italy, with a more rigid labor market, would exhibit a lower net employment elasticity to shocks like an exchange rate swing. On the contrary, our explanation for the more sizable and statistically significant responses that we document deals with the type of data used. Estimation with aggregate industry data is bound to yield an employment elasticity which is lower than the one one obtained with firm-level data. The reason for this lies in the significant employment reallocation patterns across-firms characterizing industrialized economies, which are documented to occur even within narrowly defined industries. ${ }^{10}$ A large body of literature has focused on this employment (and, in general, resource) reallocation process across plants, pointing to the large heterogeneity at the firm level as the natural explanation. Such heterogeneity can be characterized with respect to differences in the development of new products and new production techniques, to differences in entrepreneurial and managerial ability, to the uneven diffusion of information and knowledge or to the occurrence of firm and plantspecific disturbances. Aggregating firm-level data does not allow to capture the within-industry job reallocation driven by currency swings, leading to a downward bias in the estimation of the coefficient of exchange rate.

The signs and magnitudes of the other estimated coefficients are also sensible. Changes in total sales and the level of profit margins (the mark-up) have a positive and statistically significant effect on employment. Similarly, the coefficient of the lagged dependent variable, which accounts for pos-

\footnotetext{
${ }^{9}$ Whilst, as elucidated in the previous section, we use the permanent component of exchange rate variation in the empirical specification, the results are not significantly altered if actual exchange rate movements are considered. In that case, for example, the estimated response through the expenditure side would be 2.622 (with a standard error of 1.191 ) and the one through the revenue side -1.243 (with a standard error of 0.207 ). All the results for this and the other specifications of the paper using the actual exchange rate variations, instead of their permanent component, are not reported for space constraints. They are, however, qualitatively very similar to the corresponding findings documented in the paper, and are available from the authors upon request.

${ }^{10}$ We tackle this issue in more details by aggregating our firm-level data at the industry level and by replicating estimation of equation (??) on these data. Contrary to the findings documented earlier, the estimated effects of $\alpha_{i t-1} \Delta e_{t}$ and $\chi_{i t-1} \Delta e_{t}$ on employment have the expected sign but are not statistically significant.
} 
sible persistence in the firm-level adjustment process of the workforce, is positive and statistically significant. The inclusion of a variety of controls in the specification is also justified, as shown by the Wald tests for the joint significance of several groups of dummy variables for time, firm's industry, size and geographic location. Moreover, the value of the Hansen statistic for over-identifying restrictions, testing the hypothesis of lack of correlation between the instruments and residuals, and the value of the test for absence of second-order serial correlation of residuals both point to the validity of our specification. ${ }^{11}$

By evaluating the share of export revenues and the share of imported input costs at their median values, the net elasticities of employment with respect to exchange rate variations, estimated through equation (??) (see table 2 column 2), would be 0.03 . Hence, assuming identical variations of the export and import exchange rates, the effect of a one per cent depreciation on employment for a hypothetical firm exhibiting these median values of international exposure is almost zero. However, whilst, on average, the combination of two effects stemming from the revenue and the cost sides point to a negligible estimated elasticity, there may be significant differences in the magnitude of the response at the firm level. Our estimates show that, for an hypothetical firm with a share of export revenues of 0.50 (the value at the 75 th percentile) and a share of imported inputs of 0.10 (the value at the 25 th percentile), a one per cent depreciation of the export and import exchange rates determines a 0.33 per cent rise in employment. Therefore, we do believe that our own empirical framework is not ideal for assessing the effect on aggregate employment of exchange rate movements. Other types of data that span the whole economy and other types of methodologies are more appropriate for this analysis. However, our approach and our data are particularly suitable for capturing the transmission channels at the firm-level. A notable feature of this framework is that it permits to derive a firm-specific, time-varying effects.

In column 3 and 4 of table 2 we report the results from estimating equation (??) using the number of hours worked within each firm as dependent variable, instead of employment. As in the latter case, the estimated effect of exchange rate variations arising through changes in the proceeds from foreign sales is always negative and significantly different from zero at the 95 per cent level (in the specification documented in column 4 the coefficient is -0.444 with a standard error of 0.189 ),

\footnotetext{
${ }^{11}$ In the SIM survey firms' officials were also asked to report their expected value of the number of employees over the subsequent year. We then used expected change in employment as dependent variable and run a specification similar to the one documented in table 2 (column A). Interestingly enough, also in this case the effect of permanent exchange rate movements on expected employment variation is significant, through both the cost and the revenue side of the balance sheet. In particular, the estimated coefficient associated to $\alpha_{i t-1} \cdot \Delta p m e r_{t}$ is 2.591 with a standard error of 0.666 , while the one of $\chi_{i t-1} \cdot \Delta$ peer $_{t}$ is -0.779 , with a standard error of 0.129 (results are available from the authors upon request).
} 
whilst the coefficient measuring the effect through changes in costs of imported inputs is positive and statistically significant at the 95 per cent level (4.461 with a standard error of 1.008).

The coefficients associated to total sale changes and the profit margins are positive and statistically significant and, again, the values of the Wald test for the joint significance of the groups of control dummy variables point to their relevance in the equation. Moreover, the values of the Hansen test and of the test statistic for lack of second-order serial correlation of residuals from the firstdifferenced equation in general lend support to the validity of the specification.

On a priori grounds, we would expect the estimated effect of exchange rate on hours to be larger (in absolute value) than that on employment, due to the sizeable adjustment costs that typically characterize employment decisions, inducing firms to operate more on the intensive margin (number of hours per employee) and less on the extensive margin (number of employees). Firms' reliance on labor hoarding is particularly important for the Italian economy, where labor market rigidities have been largely documented to be significant. During cyclical fluctuations, in general, a firm finds it easier to adjust labor input by using overtime, adding a shift or, during recessions, by resorting to temporary lay-offs (the so called Cassa Integrazione Guadagni, which does not affect average employment). Strictly speaking, however, this firm's tendency is more pronounced when the type of shock hitting the producer is transitory rather than permanent. Since we focus on the permanent component of exchange rate movements and, in general, exchange rate shocks tend to be persistent, it is an empirical question as to whether the job response is indeed smaller that the hours worked response. Our findings document that the estimated effect of exchange rate through the cost channel is much larger on hours than it is on employment (4.461 vs. 2.432, see column 2 and 4). By contrast, when the revenue channel of the balance sheet is considered, the employment response

turns out to be stronger than the hour response $(-0.444$ vs -1.169$)$. However, if we evaluate the extent of export dependence and import reliance of each firm $\left(\chi_{i t}\right.$ and $\left.\alpha_{i t}\right)$ at the median value, it turns out that the elasticity of total manhours with respect to exchange rate variations is equal to 0.47 . This value is much larger than the corresponding close-to zero value of the employment elasticity reported before for median values of international exposure. This lends some support to the view that the hours response is, in general, stronger than the employment response.

\subsection{Market Power}

As shown by the theoretical model of section 2, the effects of exchange rate fluctuations on labor inputs is shaped by the extent of external orientation both on the cost and revenue side, but it is also amplified for firms with low market power. In table 3 we present the results from estimating 
our baseline specification splitting the sample according to the median of firms' mark-ups. As predicted by our model, and consistent with the findings obtained by Campa and Golberg (2001), the effect of exchange rate fluctuations on employment and hours is stronger for firms with a low mark-up. For these firms, the negative and statistically significant coefficient measuring the effect of exchange rate variations on employment through the revenue channel $(-0.865$ with a standard error of 0.081$)$ is larger in absolute value than that for high mark-up firms $(-0.285$ with a standard error of 0.077). Similarly, the coefficient measuring the effect through the cost side is larger for low mark-up firms (1.974 with a standard error of 0.476) than it is for high mark-up firms (1.695 with standard error of 0.510). As in the previous cases, the test diagnostics confirm the validity and soundness of the empirical specification. The response of hours worked to exchange rate changes is also stronger for low mark-up firms. Indeed, as documented in table 3, for these firms the estimated effect on both the cost and revenue channels is, in absolute value, larger than the corresponding effect for firms with relatively high price-cost margins.

In order to investigate in further detail how the relationship between exchange rate variation, foreign exposure and labor inputs is shaped by the extent of firms' market power, we also considered an empirical specification which explicitly includes the market power index described in section 3 . In particular, we have interacted the foreign exchange rate variations on the export and import sides with both the external orientation terms and the market power index. In practice, we have replaced in equation (??) the two interaction terms on the revenue and cost side with, respectively, the following two terms:

$$
\left(1-\text { mkup }_{i t-1}\right) \cdot \chi_{i t-1} \cdot \Delta \text { peer }_{t}
$$

and

$$
\left(1-\operatorname{mkup}_{i t-1}\right) \cdot \alpha_{i t-1} \cdot \Delta \text { pmer }_{t}
$$

This specification resembles more closely the expression for the labor elasticity to exchange rate that we derived in the theoretical model, where the components related to both the revenue and cost sides are pre-multiplied by a decreasing function of the mark-up (see, in particular, equation $(? ?))$. On the revenue side of the balance sheet, a negative coefficient multiplying the three interacting variables in (??) indicates that an exchange rate depreciation has a positive effect on hours and employment and that such effect increases with the firm's share of export revenues and decreases with its monopoly power. Conversely, on the cost side, a positive coefficient multiplying the interacting terms in (??) implies that an exchange rate depreciation has a negative effect on labor inputs, which increases with the firm's reliance on imported inputs and, again, decreases with its monopoly power. 
Table 4 presents the estimation results from running this empirical specification. For both employment and total hours, the coefficients of the two interacting terms written above have the expected sign and are statistically significant. For example, in the equation for total hours, these two coefficients for the revenue and cost channels are, respectively, -0.584 and 3.265 (with standard error of, respectively, 0.192 and 0.875 ). To appraise the practical implications of these latter findings, let us consider two firms with an identical external exposure on the revenue and cost sides (the average value of $\chi_{i t}$ and $\alpha_{i t}$ ) but with different monopoly power. Specifically, one has a mark-up equal to the 25th sample percentile and the other one has a mark-up equal to the 75 th sample percentile. Under these two hypotheses, the net hours elasticity to exchange rate would decrease from 0.9 to 0.8 .

\section{$5 \quad$ Further Characterizations}

We have documented that the degree of firm's foreign exposure shapes the labor response to exchange rate shocks. In particular, a high reliance on revenues from foreign sales and on imported inputs magnifies the reaction of jobs and hours worked. In the following, we will consider a number of additional implications of the relationship between exchange rates and employment that, although not all explicitly caught in our simple theoretical framework, can nonetheless find sound economic rationale and are therefore worth an empirical investigation.

\subsection{Input Penetration, Input Substitutability and Worker Types}

An additional transmission channel of exchange rate variation to labor inputs - that is particularly relevant for firms highly exposed to domestic rather than foreign markets - is the degree of import penetration. For a given non-zero value of the exchange-rate pass-through elasticity on import prices, a currency depreciation makes imported products more expensive, and therefore less competitive in the internal market. Domestic firms experience therefore a rise in their marginal profitability (and thereby on employment and hours worked), that is larger the higher is the share of domestic sales on total revenue $\left(1-\chi_{i t}\right)$, and the degree of competition from foreign suppliers, that can be proxied by the extent of industry's $j$ import penetration $\left(I P_{j t}\right.$, measured as the ratio of total import of goods of the $j$-th industry in domestic demand for goods of the $j$-th industry).

To see that this prediction is actually a feature of our theoretical model, let us consider the expression derived in section 2 for the labor elasticity to exchange rate change (see eq. (??)). In that

expression the following entity can be singled out: $A \cdot(1-\chi) \cdot \eta_{p, e}$, where $A=\frac{T R}{\bar{\mu}} \frac{a_{1}}{L\left(2 L-a_{0}+a_{2} y\right)}$ 
and $\eta_{p, e}$ is the domestic pass-through elasticity measuring the domestic price reaction to exchange rate changes. Under monopolistic competition, the higher is the foreign pressure exerted on the domestic market through import penetration, the higher is the domestic price elasticity to exchange rate (Dornbusch, 1987). Hence, as stressed by Campa and Goldberg (2001), the domestic price elasticity to exchange rate is proportional to import penetration, $\eta_{p, e} \propto I P_{j t}$.

To investigate this additional transmission channel of exchange rate movements, we augmented our baseline specification as follows:

$$
\begin{aligned}
\Delta n_{i t}=\beta_{0}+\beta_{1} \alpha_{i t-1} \Delta e_{t}+\beta_{2} \chi_{i t-1} \Delta e_{t} & +\beta_{3} \Delta s_{i t-1}+\beta_{4} m k u p_{i t-1}+\beta_{5} \Delta n_{i t-1}+ \\
& +\sum_{j=1}^{K}\left[\gamma_{j}\left(1-\chi_{i t-1}\right) I P_{j t-1} \Delta e_{t} D_{j}\right]+b^{\prime} Z_{i t}+\lambda_{i}+u_{i t}
\end{aligned}
$$

where $D_{j}$ is a dummy variable for each industry $j$, taking the value of one if firm $i$ belongs to industry $j$ and zero otherwise, and the sector $j$ import penetration ratio, $I P_{j t-1}$ enters the specification with a one year lag in order to avoid the possible simultaneity effects running from exchange rate to import pressure. The expected sign for the $\gamma_{j}$ industry-specific coefficients (with $j=1,2, \ldots, K$ ) is negative, because an exchange rate appreciation has a stronger negative effect on employment and hours worked for firms more dependent on domestic sales in sectors with higher import penetration. Moreover, it is of additional interest to test whether these sectoral coefficients differ among each other.

In table 5 we report the estimation results from running the above specification. The coefficients of the variables of the baseline specification have the expected sign and are statistically significant. The only exception is the coefficient of $\alpha_{i t-1} \cdot \Delta$ pmer $_{t}$, which still has the correct sign but looses significance, possibly because of some collinearity with the measures of import penetration. Interestingly enough, the Wald test for the joint hypothesis that industry-specific coefficients summarizing the effect of exchange rate through import penetration are identical is strongly rejected (with a p-value of 0.00), meaning that the extent of import penetration in each industry, combined with differences across firms in the exposure to domestic revenues, introduces another significant source of heterogeneity across sectors and firms in the labor response to exchange rate. Moreover, in table 6 we report the values of the industry-specific job elasticities to exchange rate through the import penetration channel, computed using the industry-specific average value across firms and over time of $\left(1-\chi_{i t-1}\right)$ and the time average of $I P_{j t}$ for each industry, and the rank for each of these industry estimated elasticities. In the same table, the estimated elasticities can be compared with the corresponding time-average values of import penetration, also accompanied by their ranks. Interestingly, the effects of currency swings on employment through the domestic revenue 
side are stronger for industries such as Chemicals, Computers and Office equipment and Machinery (both Electrical machinery and Machinery for industry and agriculture), where the degree of import penetration, and therefore foreign competition, is higher. To investigate the link between these industry-specific revenue-side elasticities and the degree of import penetration, we also computed the Spearman's rank correlation. The value of this coefficient is positive and equal to 0.34, providing further evidence that the labor response to exchange rate induced by foreign pressure in the domestic market is increasing in the degree of import penetration in each industry.

An additional issues that we investigated is whether the labor response to exchange rate through the cost side depends on the degree of substitutability between inputs within the production function. Indeed, if an exchange rate depreciation makes imported inputs more expensive, the effect on marginal profitability and thereby on input choice through the cost side of the balance sheet should depend on how imported inputs can be substituted with domestic inputs. As this depends on technological features of the production process, it is reasonable to expect that it varies from one industry to the other. In order to tackle this aspect, in an unreported regression we estimated the baseline specification (eq. (??)) augmented with sector-specific coefficients associated with the term $\alpha_{i t-1} \Delta e_{t}$. If differences across industries in the degree of input substitutability are indeed relevant, this should introduce another degree of specificity in the total hours response to exchange rate. We conducted a Wald test for the joint hypothesis that sectoral differences among the coefficients summarizing the cost-side effects on hours of exchange rate changes are equal to zero. The results confirmed that sectoral differences in the hours response through the cost side are indeed statistically significant. However, the effect of an exchange rate appreciation employment and hours worked remains positive for all sectors through the cost side and negative on the revenue side, consistent with the predictions of our theoretical framework.

Further, we analyzed whether the reaction of employment and hours worked to exchange rate changes depends on the type o workers employed in each firm. In particular, following Campa and Goldberg (2001), we regressed the estimated firm- and time-specific elasticities of employment and hours worked (obtained, respectively, as $2.432 \cdot \alpha_{i t-1}-1.169 \cdot \chi_{i t-1}$ and $4.461 \cdot \alpha_{i t-1}-0.444 \cdot \chi_{i t-1}$ ) on the firm's share of blue- and white-collar workers. Consistent with the fact that, during our sample period, labor market flexibility was lower for blue-collars, table 7 shows that the higher is firm's reliance on blue-collars, the lower is the job and hours response to currency swings. 


\subsection{The Implications for Wages of Exchange Rate Shocks}

Firms can react to exchange rate swings not only through changes in their use of labor inputs, but also modifying the wage that they offer. Based on equation (??), we can postulate the following dynamic empirical specification for wages:

$$
\Delta w_{i t}=\delta_{0}+\delta_{1} \alpha_{i t-1} \Delta e_{i t}+\delta_{2} \chi_{i t-1} \Delta e_{i t}+\delta_{3} \Delta s_{i t-1}+\Delta_{4} m k u p_{i t-1}+\delta_{5} \Delta l_{i t-1}+d^{\prime} Z_{i t}+\tau_{i}+v_{i t}
$$

where, as before, lower-case letters refer to the logarithmic transformation of the variable, $w_{i t}$ represents real wages per employee, and $l_{i t}$ is the employment level of firm $i$ at time $t$.

Table 8 reports the results from estimating the above specification. Consistently with the model's implications, we find that an exchange rate depreciation induces a real wage increase through the revenue channel. Indeed, the estimated coefficient associated with $\chi_{i t-1} \cdot \Delta$ peer $_{t}$ is -0.627 and it is statistically different from zero (the standard error is 0.181). Moreover, we also document that a depreciation causes the real wage to diminish through the transmission channel based on costs, with an estimated coefficient for $\alpha_{i t-1} \cdot \Delta$ pmer $_{t}$ of 3.793 and a standard error of 0.970 . The values of the diagnostic tests provide evidence in favor of the validity of our specification.

These results are in line with those documented by Campa and Goldberg (2001) on industry data. We have argued above that the intense job reallocation process within industries is likely to explain the low employment elasticity to exchange rate documented by Campa and Goldberg as compared to our own estimates obtained on firm-level data. The fact that such divergence is significantly reduced when dealing with the estimated wage response to exchange rate changes does not contradict the interpretation of the results for job elasticity and, more in general, it does not play down the relevance of job reallocation process, even within narrowly defined industries. Indeed, our findings are consistent with the evidence that the intense job reallocation taking place within industries is usually accompanied by a wage reduction for those workers who are re-employed (see Kletzer, 2000).

Also in the case of wages, the effect of the exchange rate fluctuations is stronger for firms with lower monopoly power. The results presented in the first two columns of table 9 , obtained splitting the sample between low- and high-monopoly power firms, confirm that the wage response to exchange rate changes through the cost channel is stronger for firms with low price-cost margins, although in this case the response through the revenue channel turns out to be not statistically different from zero. The results of the last column of table 9, obtained introducing in the basic specification the interaction terms described in expressions (??) and (??), also confirm that the sensitivity of wages to exchange rate fluctuations is a decreasing function of the firm's market power on both the cost 
and the revenue sides.

\subsection{Exchange Rate and Firm-level Gross Job Flows}

Although the focus of this paper is on the effects of exchange rate movements on employment and hours worked, we have also tested if currency swing affect the volume of job creation and job destruction. An important body of literature has focused on the impact of exchange rate fluctuations on inter-industry and intra-industry job reallocation. These contributions, which include Gourinchas (1998 and 1999) and Klein et al. (2002 and 2003), appraise the extent of the gross and net job reallocation following real exchange movements, and eventually assess how variation in job creation and job destruction brings about changes in net employment. ${ }^{12}$

We take a narrower perspective than that of the existing studies in this area of research and avoid investigating the degree of inter-industry and intra-industry job reallocation. Instead, we provide a further characterization at the firm-level of the employment response in the aftermath of a currency movement. In particular, we use our survey information on job creation and job destruction to investigate whether a given change of net employment induced by exchange rate shocks is associated with high or low levels of job reallocation within the firm.

We use two measures of gross job reallocation as dependent variables: the gross job reallocation rate,

$$
\operatorname{gjrr}_{i t}=\frac{C_{i t}+D_{i t}}{\frac{1}{2}\left(L_{i t}+L_{i t-1}\right)},
$$

and the excess job reallocation rate (Davis and Haltiwanger, 1999),

$$
\operatorname{ejrr}_{i t}=\frac{C_{i t}+D_{i t}-\left|C_{i t}-D_{i t}\right|}{\frac{1}{2}\left(L_{i t}+L_{i t-1}\right)}
$$

where $C_{i t}$ and $D_{i t}$ are job creation and job destruction, respectively. While the first measure accounts for total job reallocation, the second focuses only on the amount of job reallocation in

\footnotetext{
${ }^{12}$ In a nutshell, the major findings of this literature can be summarized as follows: a) in the U.S. traded good sector, real exchange rate variations induce movements in the same direction for both job creation and job destruction; b) after an appreciation, both job creation and job destruction increase, with the latter rising by more (thus, net employment declines and job reallocation rises); c) following a depreciation, job creation and job destruction go down in the same proportion, thus reducing job reallocation. Therefore, when a currency depreciates, firms in the U.S. traded good sector experience a "chill" whilst, during appreciation episodes, they experience a "churn" (Gourinchas, 1998). The picture emerging from the French economy is somewhat different because job creation and job destruction are more responsive to exchange rate than they are in the U.S. and also they move in opposite direction, with job creation reacting more strongly to exchange rate than job destruction (see Gourinchas, 1999 and Klein et al., 2002).
} 
excess to what is associated with changes in net employment. Table 10 documents the empirical findings from our investigation. The results in the first two columns of table 10 seem to suggest that exchange rate movements induce a significant job reallocation within each firm. Indeed, the coefficients on both the cost and revenue's transmission channels are statistically significant. For example, in the specification where gross job reallocation rate is the dependent variable the coefficient associated with $\alpha_{i t-1} \cdot \Delta p m e r_{t}$ is 4.579 (with a standard error of 2.551) and the one associated with $\chi_{i t-1} \cdot \Delta$ peer $_{t}$ is -0.971 (with a standard error of 0.434 ). However, when we turn to investigate separately the job creation rate and the job destruction rate (columns 3 and 4 ), we find support to the view that exchange rate movements induce significant changes on the rate of job creation, with both coefficients on the revenue and on the cost side with the expected signs and statistically different from zero at the 5 per cent level, but their effects on job destruction are not significantly different from zero. While by no means can these results be compared with those of the previous literature, because our empirical framework is profoundly different, the results show that the degree of job reallocation following a currency shock is primarily the result of movements in job creation, rather than in job destruction.

\section{Conclusion}

We document a statistically significant effect of exchange rate variations on employment, hours worked and wages in a representative panel of Italian manufacturing firms. Our primary contribution lies in the investigation of a number of mechanisms at the firm level underlying this finding. We show that the degree of firm's foreign exposure on both the revenue and the cost side of the balance sheet determines the direction and size of the hours and job response to a currency swing. We estimate a time-varying response for each individual firm, reflecting the type and extent of such external orientation. Moreover, we show that, for a given degree of international exposure, the effects of exchange rate on employment and hours are magnified when the firm exhibits a low level of monopoly power, and that the response is stronger when firms face a significant foreign pressure on their domestic markets, through a high degree of import penetration. Other features, like the degree of substitutability in the production process between imported and other inputs or the type of workers employed in each firm are shown to introduce an additional degree of specificity in the employment reaction to exchange rate. We also estimate the wage response to exchange rate shocks, which is significant and again dependent upon firm's foreign exposure. A further characterization of the implications of exchange rate on labor market variables deals with the amount of gross job flows within each firm in the aftermath of a currency shock. Whilst we provide some 
evidence that job reallocation within firms is sensitive to exchange rate movements, our findings, however, support the view that job creation is significantly more reactive than job destruction.

Overall, our results show that the aggregate relationship between the exchange rate and the level of employment hinges upon a wide set of characteristics of the firms operating in the manufacturing sector, and therefore currency fluctuations can have very heterogenous effects at the firm level. 
Table 1

Summary statistics

\begin{tabular}{l|rrrrr}
\hline \hline Variable & Mean & \multicolumn{1}{l}{$\begin{array}{l}\text { St. } \\
\text { dev. }\end{array}$} & Median & $\begin{array}{l}\text { 25th } \\
\text { perc. }\end{array}$ & $\begin{array}{l}75 \text { th } \\
\text { perc. }\end{array}$ \\
\hline Import exchange rate (growth rate) & -0.00 & 0.05 & 0.00 & -0.03 & 0.02 \\
Export exchange rate (growth rate) & -0.01 & 0.06 & -0.01 & -0.03 & 0.02 \\
Share of expenditure on imported input & 0.14 & 0.06 & 0.13 & 0.10 & 0.17 \\
Share of revenues from export & 0.31 & 0.25 & 0.27 & 0.05 & 0.50 \\
Mark-up & 0.09 & 0.25 & 0.09 & 0.06 & 0.14 \\
Employment (growth rate) & -0.01 & 0.11 & -0.01 & -0.05 & 0.03 \\
Total manhours (growth rate) & -0.01 & 0.16 & -0.00 & -0.06 & 0.05 \\
Hourly wage (growth rate) & 0.00 & 0.18 & 0.01 & -0.04 & 0.05 \\
Average wage (growth rate) & 0.01 & 0.16 & 0.01 & -0.03 & 0.05 \\
Total sales (growth rate) & 0.00 & 0.23 & 0.01 & -0.08 & 0.10 \\
\hline \hline
\end{tabular}


Table 2

The effect of permanent exchange rate change on employment and hours worked

\begin{tabular}{|c|c|c|c|c|}
\hline & $(1)$ & $(2)$ & $(3)$ & (4) \\
\hline Variable & \multicolumn{2}{|c|}{ Employment: $\Delta l_{i t}$} & \multicolumn{2}{|c|}{ Manhours: $\Delta h_{i t}$} \\
\hline \multirow[t]{2}{*}{$\alpha_{i t-1} \cdot \Delta p m e r_{t}$} & $3.137^{* *}$ & $2.432^{* *}$ & $4.556^{* *}$ & $4.461^{* *}$ \\
\hline & $(1.237)$ & $(0.958)$ & $(1.243)$ & $(1.008)$ \\
\hline \multirow[t]{2}{*}{$\chi_{i t-1} \cdot \Delta$ peer $_{t}$} & $-1.442^{* *}$ & $-1.169^{* *}$ & $-0.725^{* *}$ & $-0.444^{* *}$ \\
\hline & $(0.227)$ & $(0.186)$ & $(0.215)$ & $(0.189)$ \\
\hline \multirow[t]{2}{*}{$\Delta s_{i t-1}$} & $0.033^{* *}$ & $0.025^{* *}$ & $0.036^{* *}$ & $0.031^{* *}$ \\
\hline & $(0.005)$ & $(0.004)$ & $(0.006)$ & $(0.005)$ \\
\hline \multirow[t]{2}{*}{ mkup $_{i t-1}$} & - & $0.216^{* *}$ & - & $0.188^{* *}$ \\
\hline & & $(0.027)$ & & $(0.020)$ \\
\hline \multirow[t]{2}{*}{ Lagged dependent variable } & $0.162^{* *}$ & $0.166^{* *}$ & 0.018 & 0.003 \\
\hline & $(0.013)$ & $(0.011)$ & $(0.012)$ & $(0.010)$ \\
\hline \multirow[t]{2}{*}{ Constant } & $-0.306^{* *}$ & -0.160 & $-0.276^{* *}$ & -0.114 \\
\hline & $(0.109)$ & $(0.101)$ & $(0.137)$ & $(0.129)$ \\
\hline Year dummies & $156.8(0.0)$ & $141.4(0.0)$ & $279.4(0.0)$ & $305.3(0.0)$ \\
\hline Industry dummies & $243.9(0.0)$ & $148.1(0.0)$ & $102.1(0.0)$ & $105.3(0.0)$ \\
\hline Geography dummies & $19.3(0.0)$ & $19.9(0.0)$ & $30.6(0.0)$ & $38.4(0.0)$ \\
\hline Firm size dummies & $16.1(0.0)$ & $13.3(0.0)$ & $33.16(0.0)$ & $29.9(0.0)$ \\
\hline Hansen test of over-identifying restrictions: & $174.3(0.06)$ & $243.3(0.05)$ & $266.8(0.08)$ & $348.5(0.04)$ \\
\hline Test for second-order serial correlation & $0.26(0.79)$ & $-0.15(0.89)$ & $-1.52(0.13)$ & $-1.84(0.07)$ \\
\hline
\end{tabular}

Notes: Estimates are obtained using the system GMM dynamic panel estimator. $\alpha_{i t-1}$ is the share of cost for imported inputs and $\chi_{i t-1}$ is the share of revenues from export. $\Delta$ pmer $_{t}$ and $\Delta p e e r_{t}$ are the (log) changes in the permanent component of, respectively, the import and export exchange rate. $\Delta s_{i t-1}$ is the (log) change of real sales and mkup $_{i t-1}$ is the firm's mark-up. Size dummies refer to these sizes: $50-99,100-199,200-499,500-999$, $\geq 1000$ employees. Geographic dummies refer to North-West, North-East, Center, South, Islands. For each group of dummies we report the value of Wald test of their joint significance and the associated p-value. Standard errors are reported in parentheses. They are corrected for heteroskedasticity and incorporate the Windmeijer's finite-sample correction for their original downward bias. The instrument set includes lagged values of the dependent variable, changes of sales and the mark-up dated $t$ - 2 and earlier. Hansen is a test of over-identifying restrictions asymptotically distributed as a $\chi^{2}$. We also report the value of the test for second-order autocorrelation of the differenced residuals (the p-values are reported in parenthes). Sample period: 1984-2000. ${ }^{* *}$ denotes significance at the $5 \%$ confidence level and ${ }^{*}$ at the $10 \%$. 
Table 3

Exchange rate, employment and hours:

The role of market power (I)

\begin{tabular}{lcccc}
\hline \hline & $(1)$ & $(2)$ & $(3)$ & $(4)$ \\
\hline \multicolumn{1}{c}{ Variable } & \multicolumn{2}{c}{ Employment: $\Delta l_{i t}$} & \multicolumn{2}{c}{ Total Manhours: $\Delta h_{i t}$} \\
\hline & \multicolumn{2}{c}{ Degree of market power } & \multicolumn{2}{c}{ Degree of market power } \\
& Low & High & Low & High \\
\cline { 2 - 5 }$\alpha_{i t-1} \cdot \Delta p m e r_{t}$ & $1.974^{* *}$ & $1.695^{* *}$ & $6.045^{* *}$ & $3.169^{* *}$ \\
& $(0.476)$ & $(0.510)$ & $(0.810)$ & $(1.619)$ \\
$\chi_{i t-1} \cdot \Delta$ peer $_{t}$ & $-0.865^{* *}$ & $-0.285^{* *}$ & $-0.465^{* *}$ & -0.196 \\
& $(0.081)$ & $(0.077)$ & $(0.132)$ & $(0.333)$ \\
$\Delta s_{i t-1}$ & $0.012^{* *}$ & $0.028^{* *}$ & $0.037^{* *}$ & $0.034^{* *}$ \\
& $(0.002)$ & $(0.003)$ & $(0.004)$ & $(0.008)$ \\
$m k u p_{i t-1}$ & $0.229^{* *}$ & $0.266^{* *}$ & $0.097^{* *}$ & $0.237^{* *}$ \\
Lagged dependent variable & $(0.012)$ & $(0.021)$ & $(0.012)$ & $(0.046)$ \\
& $0.131^{* *}$ & $0.159^{* *}$ & -0.014 & -0.010 \\
Constant & $(0.008)$ & $(0.008)$ & $(0.009)$ & $(0.014)$ \\
& $-0.475^{* *}$ & 0.096 & $-0.350^{* *}$ & 0.145 \\
Year dummies & $(0.120)$ & $(0.108)$ & $(0.164)$ & $(0.189)$ \\
Industry dummies & $279.2(0.0)$ & $274.8(0.0)$ & $426.8(0.0)$ & $134.8(0.0)$ \\
Geography dummies & $69.7(0.0)$ & $259.6(0.0)$ & $16.8(0.16)$ & $50.8(0.0)$ \\
Firm size dummies & $34.7(0.0)$ & $24.9(0.0)$ & $28.1(0.0)$ & $21.4(0.0)$ \\
\hline Hansen test of over-identifying restrictions: & $316.5(0.37)$ & $313.1(0.44)$ & $334.0(0.33)$ & $195.3(0.09)$ \\
Test for second-order serial correlation & $-0.83(0.41)$ & $-0.54(0.59)$ & $-2.0(0.05)$ & $-1.59(0.11)$ \\
\hline \hline
\end{tabular}

Notes: see Table 2. Estimates are obtained by using the system GMM dynamic panel estimator. The sample is split based on the degree of firms'market power. The threshold criterion is the median of firms'mark-up. Variables in lower-case letters denote their logarithmic transformation. ${ }^{* *}$ denotes significance at the $5 \%$ confidence level and ${ }^{*}$ at the $10 \%$ level. 
Table 4

Exchange rate, employment and hours:

The role of market power (II)

\begin{tabular}{lcc}
\hline \hline \multicolumn{1}{c}{ Variable } & $(1)$ & $(2)$ \\
\hline$\alpha_{i t-1} \cdot \Delta$ pmer $_{t} \cdot\left(1-\right.$ mup $\left._{i t-1}\right)$ & Employment: $\Delta l_{i t}$ & Total Manhours: $\Delta h_{i t}$ \\
$\chi_{i t-1} \cdot \Delta$ peer $_{t} \cdot\left(1-\right.$ mkup $\left._{i t-1}\right)$ & $3.780^{* *}$ & $3.265^{* *}$ \\
& $(0.693)$ & $(0.875)$ \\
$\Delta s_{i t-1}$ & $-0.831^{* *}$ & $-0.584^{* *}$ \\
& $(0.169)$ & $(0.192)$ \\
$m k u p_{i t-1}$ & $0.021^{* *}$ & $0.032^{* *}$ \\
& $(0.003)$ & $(0.005)$ \\
Lagged dependent variable & $0.189^{* *}$ & $0.187^{* *}$ \\
& $(0.024)$ & $(0.019)$ \\
Constant & $0.157^{* *}$ & 0.003 \\
& $(0.010)$ & $(0.010)$ \\
Year dummies & -0.125 & -0.140 \\
Industry dummies & $(0.094)$ & $(0.128)$ \\
Geography dummies & $212.4(0.0)$ & $307.1(0.0)$ \\
Firm size dummies & $204.9(0.0)$ & $99.6(0.0)$ \\
\hline Hansen test of over-identifying restrictions: & $298.1(0.07)$ & $39.3(0.0)$ \\
Test for second-order serial correlation & $-0.40(0.69)$ & $-1.92(0.06)$ \\
\hline \hline
\end{tabular}

Notes: see Table 2. Estimates are obtained by using the system GMM dynamic panel estimator. $m k u p_{i t}$ is the value of the firm's mark-up. Variables in lower-case letters denote their logarithmic transformation. ${ }^{* *}$ denotes significance at the $5 \%$ confidence level and ${ }^{*}$ at $10 \%$ level. 
Table 5

Exchange rate and employment:

The role of input penetration

\begin{tabular}{|c|c|}
\hline Variable & Employment: $\Delta l_{i t}$ \\
\hline \multirow[t]{2}{*}{$\alpha_{i t-1} \cdot \Delta$ pmer $_{t}$} & 2.310 \\
\hline & $(2.810)$ \\
\hline \multirow[t]{2}{*}{$\chi_{i t-1} \cdot \Delta$ peer $_{t}$} & $-2.654^{* *}$ \\
\hline & $(1.011)$ \\
\hline \multirow{2}{*}{$\begin{array}{c}\left(1-\chi_{i t-1}\right) \cdot \Delta \text { peer }_{t} \cdot I P_{1 t-1} \cdot D_{1}, \quad\left(1-\chi_{i t-1}\right) \cdot \Delta \text { peer }_{t} \cdot I P_{2 t-1} \cdot D_{2}, \ldots . \\
\ldots,\left(1-\chi_{i t-1}\right) \cdot \Delta \text { peer }_{t} \cdot I P_{K t-1} \cdot D_{K}\end{array}$} & Wald test: \\
\hline & 48.1 ( $p$-val: 0.00$)$ \\
\hline \multirow[t]{2}{*}{$\Delta s_{i t-1}$} & $0.029^{* *}$ \\
\hline & $(0.005)$ \\
\hline \multirow[t]{2}{*}{$m k u p_{i t-1}$} & $0.231^{* *}$ \\
\hline & $(0.036)$ \\
\hline \multirow[t]{2}{*}{ Lagged dependent variable } & $0.148^{* *}$ \\
\hline & $(0.013)$ \\
\hline \multirow[t]{2}{*}{ Constant } & $-0.350^{* *}$ \\
\hline & $(0.159)$ \\
\hline Year dummies & $133.6(0.0)$ \\
\hline Industry dummies & $59.5(0.0)$ \\
\hline Geography dummies & $17.3(0.0)$ \\
\hline Firm size dummies & $8.9(0.06)$ \\
\hline Hansen test of over-identifying restrictions: & $178.2(0.14)$ \\
\hline Test for second-order serial correlation & $1.54(0.12)$ \\
\hline
\end{tabular}

Notes: see Table 2. Estimates are obtained by using the system GMM dynamic panel estimator. IP $j t$ is the value of import penetration experienced by industry $j$ in the year $t$. $\mathrm{D}_{j}$ is the $j$-th industry dummy, taking the value of one if firm $i$ belongs to industry $j$ and zero otherwise. The Wald statistic associated with the variables $\left(1-\chi_{i t-1}\right) \cdot \Delta$ peer $_{t} \cdot I P_{j t-1} \cdot D_{j}(j=1,2, \ldots, K)$ tests for the hypothesis that their coefficients are equal. Variables in lower-case letters denote their logarithmic transformation. ${ }^{* *}$ denotes significance at the $5 \%$ confidence level and * at the $10 \%$ level. 
Table 6

Industry heterogeneity in input penetration and the employment response

\begin{tabular}{lcc|cc}
\hline \hline \multirow{2}{*}{\multicolumn{1}{c}{ Industry }} & \multicolumn{2}{c|}{$\begin{array}{c}\text { Import } \\
\text { penetration }\end{array}$} & \multicolumn{2}{l}{$\begin{array}{l}\text { Response through } \\
\text { import penetration }\end{array}$} \\
\cline { 2 - 5 } Transformation of non metalliferous minerals & 0.10 & 14 & -0.49 & 13 \\
\cline { 2 - 5 } Chemicals & 0.35 & 3 & -1.47 & 2 \\
Metals & 0.05 & 15 & -0.69 & 9 \\
Machinery for industry and agriculture & 0.25 & 5 & -1.61 & 1 \\
Computers, office equipments, precision instruments & 0.58 & 1 & -1.42 & 4 \\
Electrical machinery & 0.29 & 4 & -0.97 & 6 \\
Motor-cars and other transport equipments & 0.54 & 2 & -0.45 & 14 \\
Food and tobacco products & 0.16 & 7 & -0.61 & 11 \\
Textiles & 0.16 & 8 & -0.58 & 12 \\
Leather and footwear & 0.17 & 6 & -1.31 & 5 \\
Clothing & 0.14 & 12 & -0.14 & 15 \\
Wood and furniture & 0.15 & 11 & -0.71 & 8 \\
Paper and publishing & 0.12 & 13 & -1.43 & 3 \\
Rubber and plastic products & 0.15 & 9 & -0.62 & 10 \\
Other manufactures & 0.15 & 10 & -0.88 & 7 \\
\hline \hline
\end{tabular}

Notes: Import penetration for each industry is defined in the text and industry time averages are reported here with the corresponding ranks. We also report industry-specific estimates of the exchange rate effect on employment that arises through import penetration. The estimates are obtained from the results of the specification documented in Table 5; we also report the ranks of (the absolute values of) these estimated effects. 
Table 7

Workers type and the employment and hours response

\begin{tabular}{|c|c|c|}
\hline \multirow{3}{*}{ Variable } & (1) & $(2)$ \\
\hline & Estimated employment response & Estimated hours response \\
\hline & $2.432 \cdot \alpha_{i t-1}-1.169 \cdot \chi_{i t-1}$ & $4.461 \cdot \alpha_{i t-1}-0.444 \cdot \chi_{i t-1}$ \\
\hline \multirow{2}{*}{$\frac{L_{\_} \text {Blue Collars } i t}{L_{i t}}$} & $-.094^{* *}$ & $-.086^{* *}$ \\
\hline & $(.025)$ & $(.016)$ \\
\hline \multirow[t]{2}{*}{ Constant } & -.178 & $.240^{* *}$ \\
\hline & $(.152)$ & $(.096)$ \\
\hline Year dummies & $52.3(.00)$ & $554.2(.00)$ \\
\hline Industry dummies & $8.0(.00)$ & $15.2(.00)$ \\
\hline Geography dummies & $.43(.73)$ & $0.6(.72)$ \\
\hline Firm size dummies & $5.6(.00)$ & $8.0(.00)$ \\
\hline Hausman test & $120.9(.00)$ & $403.8(.00)$ \\
\hline
\end{tabular}

Notes: The dependent variables are the responses of, respectively, employment and hours to permanent exchange rate variations as obtained through the estimation process documented in Table 2. The explanatory variable is the firm-level share of blue-collar workers over total workers. Fixed effects panel estimation method has been applied and values of the Hausman test are reported (with the associated p-value). ${ }^{* *}$ denotes significance at the $5 \%$ confidence level and ${ }^{*}$ at the $10 \%$ level. 
Table 8

The effect of permanent exchange rate change on wages

\begin{tabular}{|c|c|c|}
\hline & $(1)$ & $(2)$ \\
\hline Variable & \multicolumn{2}{|c|}{ Real wages: $\Delta w_{i t}$} \\
\hline \multirow[t]{2}{*}{$\alpha_{i t-1} \cdot \Delta p m e r_{t}$} & $3.793^{* *}$ & $2.670^{* *}$ \\
\hline & $(0.970)$ & $(0.712)$ \\
\hline \multirow{2}{*}{$\chi_{i t-1} \cdot \Delta$ peer $_{t}$} & $-0.627^{* *}$ & $-0.597^{* *}$ \\
\hline & $(0.181)$ & $(0.132)$ \\
\hline \multirow[t]{2}{*}{$\Delta s_{i t-1}$} & -0.004 & 0.002 \\
\hline & $(0.003)$ & $(0.003)$ \\
\hline \multirow{2}{*}{$m k u p_{i t-1}$} & -- & $0.131^{* *}$ \\
\hline & & $(0.013)$ \\
\hline \multirow[t]{2}{*}{$\Delta n_{i t-1}$} & 0.006 & $0.045^{* *}$ \\
\hline & $(0.012)$ & $(0.009)$ \\
\hline \multirow[t]{2}{*}{ Constant } & 0.001 & -0.026 \\
\hline & $(0.105)$ & $(0.044)$ \\
\hline Year dummies & $703.1(0.00)$ & $1090.8(0.00)$ \\
\hline Industry dummies & $51.6(0.00)$ & $47.0(0.00)$ \\
\hline Geography dummies & $7.1(0.13)$ & $7.5(0.11)$ \\
\hline Firm size dummies & $8.9(0.06)$ & $15.9(0.00)$ \\
\hline Hansen test of over-identifying restrictions: & $210.6(0.10)$ & $314.3(0.15)$ \\
\hline Test for second-order serial correlation & $1.30(0.20)$ & $1.24(0.21)$ \\
\hline
\end{tabular}

Notes: see Table 2. Estimates are obtained by using the system GMM dynamic panel estimator. $w_{i t}$ is the firm-level value of real wage per employee. Variables in lower-case letters denote their logarithmic transformation. ${ }^{* *}$ denotes significance at the $5 \%$ confidence level and ${ }^{*}$ at the $10 \%$ level. 
Table 9

Exchange rate and wages:

The role of market power

\begin{tabular}{|c|c|c|c|}
\hline \multirow[t]{2}{*}{ Variable } & \multicolumn{3}{|c|}{ Real wages: $\Delta w_{i t}$} \\
\hline & $(1)$ & $(2)$ & $(3)$ \\
\hline & \multicolumn{2}{|c|}{ Degree of market power } & All sample \\
\hline \multirow{3}{*}{$\alpha_{i t-1} \cdot \Delta$ pmer $_{t}$} & Low & High & \\
\hline & $3.231^{* *}$ & $2.864^{* *}$ & -- \\
\hline & $(0.756)$ & $(0.884)$ & \\
\hline \multirow[t]{2}{*}{$\chi_{i t-1} \cdot \Delta$ peer $_{t}$} & $-0.961^{* *}$ & -0.257 & -- \\
\hline & $(0.150)$ & $(0.166)$ & \\
\hline \multirow[t]{2}{*}{$\alpha_{i t-1} \cdot \Delta$ pmer $_{t} \cdot\left(1-\right.$ mkup $\left._{i t-1}\right)$} & -- & -- & $2.246^{* *}$ \\
\hline & & & $(0.795)$ \\
\hline \multirow[t]{2}{*}{$\chi_{i t-1} \cdot \Delta$ peer $_{t} \cdot\left(1-m k u p_{i t-1}\right)$} & -- & -- & $-0.913^{* *}$ \\
\hline & & & $(0.169)$ \\
\hline \multirow[t]{2}{*}{$\Delta s_{i t-1}$} & $0.023^{* *}$ & $-0.016^{* *}$ & 0.001 \\
\hline & $(0.003)$ & $(0.003)$ & $(0.003)$ \\
\hline \multirow[t]{2}{*}{$m k u p_{i t-1}$} & $0.132^{* *}$ & $0.163^{* *}$ & $0.149^{* *}$ \\
\hline & $(0.011)$ & $(0.033)$ & $(0.015)$ \\
\hline \multirow[t]{2}{*}{$\Delta n_{i t-1}$} & $0.083^{* *}$ & -0.017 & $0.049^{* *}$ \\
\hline & $(0.009)$ & $(0.014)$ & $(0.010)$ \\
\hline \multirow[t]{2}{*}{ Constant } & 0.096 & -0.090 & -0.021 \\
\hline & $(0.126)$ & $(0.147)$ & $(0.048)$ \\
\hline Year dummies & $644.8(0.00)$ & $587.6(0.00)$ & $755.9(0.00)$ \\
\hline Industry dummies & $46.5(0.00)$ & $48.1(0.00)$ & $39.6(0.00)$ \\
\hline Geography dummies & $10.9(0.03)$ & $14.7(0.01)$ & $7.9(0.10)$ \\
\hline Firm size dummies & $13.6(0.01)$ & $11.2(0.02)$ & $11.4(0.02)$ \\
\hline Hansen test of over-identifying restrictions: & $303.5(0.05)$ & $233.5(0.07)$ & $254.1(0.10)$ \\
\hline Test for second-order serial correlation & $1.15(0.25)$ & $1.82(0.07)$ & $1.27(0.20)$ \\
\hline
\end{tabular}

Notes: see Table 2. Estimates are obtained by using the system GMM dynamic panel estimator. $m k u p_{i t}$ is the value of the firm's mark-up. When the sample is split based on the degree of firms'market power, the threshold criterion is the median of firms'mark-up. Variables in lower-case letters denote their logarithmic transformation. ${ }^{* *}$ denotes significance at the $5 \%$ confidence level and ${ }^{*}$ at the $10 \%$ level. 
Table 10

Exchange rate implications for gross job flows at the firm level

\begin{tabular}{lcccc}
\hline \hline \multicolumn{1}{c}{ Variable } & $(1)$ & $(2)$ & $(3)$ & $(4)$ \\
& Gross job & Excess job & Job & Job \\
& reallocation & reallocation & creation & destruction \\
\cline { 2 - 5 }$\alpha_{i t-1} \cdot \Delta p m e r_{t}$ & $4.579^{*}$ & $5.571^{* *}$ & $4.539^{* *}$ & 1.426 \\
& $(2.551)$ & $(2.470)$ & $(1.684)$ & $(1.490)$ \\
$\chi_{i t-1} \cdot \Delta p e e r_{t}$ & $-0.971^{* *}$ & $-1.630^{* *}$ & $-1.371^{* *}$ & 0.192 \\
& $(0.434)$ & $(0.452)$ & $(0.309)$ & $(0.226)$ \\
$\Delta s_{i t-1}$ & $0.011^{* *}$ & $0.021^{* *}$ & $0.023^{* *}$ & -0.003 \\
& $(0.005)$ & $(0.004)$ & $(0.003)$ & $(0.003)$ \\
$m k u p_{i t-1}$ & 0.032 & $0.085^{*}$ & $0.099^{* *}$ & $-0.066^{* *}$ \\
& $(0.044)$ & $(0.048)$ & $(0.030)$ & $(0.020)$ \\
Constant & -0.250 & -0.637 & $-0.464^{* *}$ & $-0.393^{*}$ \\
& $(0.695)$ & $(0.637)$ & $(0.226)$ & $(0.207)$ \\
\cline { 2 - 5 } Year dummies & $203.1(0.0)$ & $253.1(0.0)$ & $375.2(0.0)$ & $162.6(0.0)$ \\
Industry dummies & $58.5(0.0)$ & $53.2(0.0)$ & $54.3(0.0)$ & $94.5(0.0)$ \\
Geography dummies & $17.8(0.0)$ & $26.0(0.00)$ & $34.2(0.0)$ & $13.8(0.01)$ \\
Firm size dummies & $5.5(0.07)$ & $6.4(0.04)$ & $1.4(0.50)$ & $5.9(0.12)$ \\
\hline Hansen test of over-identifying restrictions: & $61.8(0.77)$ & $68.6(0.56)$ & $93.1(0.08)$ & $75.6(0.43)$ \\
Test for second-order serial correlation & $-1.71(0.09)$ & $-0.19(0.85)$ & $-.32(0.75)$ & $-1.56(0.12)$ \\
\hline \hline
\end{tabular}

Notes: see Table 2. Estimates are obtained by using the system GMM dynamic panel estimator. The four dependent variables are defined in the text and are expressed as rates. Variables in lower-case letters denote their logarithmic transformation. ${ }^{* *}$ denotes significance at the $5 \%$ confidence level and ${ }^{*}$ at the $10 \%$ level. 


\section{References}

[1] Arellano, M. and S. R. Bond, (1991), "Some Tests of Specification for Panel Data: Monte Carlo Evidence and an Application to Employment Equations", Review of Economic Studies, 58, 277-297.

[2] Arellano M. and Bover O., (1995), "Another Look at the Instrumental Variable Estimation of Error-components Models", Journal of Econometrics, Vol 68, 1, 29-51.

[3] Banca d'Italia, (1998), "Nuovi Indicatori di Tasso di Cambio Effettivo Nominale e Reale", Bollettino Economico 30, 1*-8*.

[4] Beveridge, S. and C. R. Nelson, (1981), "New Approach to Decomposition of Economic Time Series into Permanent and Transitory Components with Particular Attention to Measurement of the 'Business Cycle", Journal of Monetary Economics, 7, 151-174.

[5] Blundell, R., and S. Bond, (2000), "GMM Estimation with Persistent Panel Data: an Application to Production Functions", Econometric Reviews, Vol 19, 3, 321 - 340.

[6] Branson, W. and Love, J., (1988), "United States Manufacturing and the Real Exchange Rate", in R. Marston (ed.) "Misalignment of Exchange Rates: Effects on Trade and Industry", University of Chicago Press.

[7] Burgess, S. and Knetter, M., (1998), "An International Comparison of Employment Adjustment to Exchange Rate Fluctuations", Review of International Economics, Vol 6, 1, 151-163.

[8] Campa, J. and L. Goldberg, (1999), "Investment, Pass-Through and Exchange Rates: a CrossCountry Comparison", International Economic Review, 40, 287-314.

[9] Campa, J. and Goldberg, L. (2001), "Employment versus Wage Adjustment and the U.S. Dollar", Review of Economics and Statistics, 83, 477-489.

[10] Davis, S.J., and Haltinwanger, J., (1999), "Gross Job Flows", in Ashenfelter, O. and Card, D., (eds.), Handbook of Labor Economics, Vol. 3, Elsevier Science.

[11] Domowitz, I., R. G. Hubbard and C. Petersen, (1986), "Business Cycles and the Relationship between Concentration and Profit Margins", Rand Journal of Economics 17, 1-17.

[12] Dornbusch, R., (1987), "Exchange Rates and Prices", American Economic Review, 77, 93-106.

[13] Goldberg, L. and Tracy, J. (2000), "Exchange Rates and Local Labor Markets", in R. Feenstra (ed.), "The Impact of International Trade on Wages", NBER and University of Chicago Press. 
[14] Gourinchas, P.O., (1998) "Exchange Rates and Jobs: What Do We Learn from Job Flows?", NBER Macroeconomics Annual, Vol 13, 153-208, Cambridge and London: MIT Press.

[15] Gourinchas, P.O., (1999), "Exchange Rates Do Matter: French Job Reallocation and Exchange Rate Turbulence, 1984-1992", European Economic Review, vol. 43, 7, 1279-1316.

[16] Klein, M.W., S. Schuh, R. K., Triest, (2002), "Job Creation, Job Destruction, and International Competition: a Literature Review", Federal Reserve Bank of Boston, Working Paper 02-7.

[17] Klein, M.W., S. Schuh, R.K., Triest, (2003), "Job Creation, Job Destruction, and the Real Exchange Rate", Journal of International Economics, Vol. 59, 2, 239-265.

[18] Kletzer, L, (2000), "Trade and Job Loss in US Manufacturing, 1979-94", in R. Feenstra (ed.), "The Impact of International Trade on Wages" NBER and University of Chicago Press.

[19] Knetter, M., (1993), "International Comparisons of Pricing-to Market Behavior", American Economic Review, 83, 473-486.

[20] Nucci, F. and A.F. Pozzolo, (2001), "Investment and the Exchange Rate: an Analysis with Firm-Level Panel Data", European Economic Review, (45)2, 259-283.

[21] Revenga, A. (1992), "Exporting Jobs? The Impact of Import Competition on mployment and Wages in U.S. Manufacturing", Quarterly Journal of Economics, 94, 3, S111-143.

[22] Yang, J., (1997), "Exchange Rate Pass-through in U.S. Manufacturing Industries", Review of Economics and Statistics, vol. 79, 95-104. 